\title{
High adiponectin levels in lean Arab women compared to Asian women
}

\author{
Mohamed Abu-Farha', Kazem Behbehani ${ }^{2}$ and Naser Elkum ${ }^{3^{*}}$
}

\begin{abstract}
Adiponectin has been recognized as a potent regulator of metabolism possessing anti-inflammatory and anti-atherogenic functions and inversely associated with increasing incidents of type 2 diabetes and obesity. In this study, we investigated the changes in adiponectin level of 193 Arab and 132 Asian women were compared. Overall, Arab women had statistically significant higher levels of adiponectin $17.84(1.047) \mu \mathrm{g} / \mathrm{mL}$ than Asians $12.87(1.049) \mu \mathrm{g} / \mathrm{mL}$. In conclusion, our data demonstrates that Arab women poses high adiponectin level compared to Asians and the protective role of adiponectin in Arab women against metabolic disorders requires further attention.
\end{abstract}

Keywords: Adiponectin, Ethnicity, Obesity, BMl, Arab, Asian

\section{To the Editor}

Adiponectin has been recognized as a potent regulator of metabolism possessing anti-inflammatory and antiatherogenic functions. Its level in human plasma is inversely associated with increasing incidents of type 2 diabetes, cardiovascular disease risk and obesity [1]. Significantly different levels of adiponectin have been reported in different ethnicities. For example, Asians have a lower adiponectin plasma level than Caucasians, which is consistent with the increased risk of metabolic disorders among Asians [1].

In this study, plasma level of adiponectin of 193 Arab and 132 Asian women living in Kuwait was assessed using the multiplexing immunobead array platform (Luminex, Austin, TX) using a 2-Plex kit (BioRad, Hercules, CA). All subjects gave their written consent to participate in the study. Full description of the study design was published by Elkum et al. [2]. Briefly, our samples were collected from the six governorates of the state of Kuwait, where random samples were collected from each stratum with proportional allocations. Adiponectin level are reported as geometric means and their standard errors according to BMI. BMI between 18.5 and 24.9 was considered lean, 25 to 29.9,

\footnotetext{
* Correspondence: nelkum@hotmail.com

${ }^{3}$ Clinical Epidemiology, Sidra Medical and Research Center, 26999, Doha, Qatar

Full list of author information is available at the end of the article
}

overweight, $\geq 30$ was considered obese). Clinical characteristics of the population are shown in Table 1.

Overall, Arab women had statistically significant higher levels of adiponectin 17.84 (1.047) $\mu \mathrm{g} / \mathrm{mL}$ than Asians $12.87(1.049) \mu \mathrm{g} / \mathrm{mL}$. Comparing across different levels of BMI, Arab lean women had the highest adiponectin level at $23.73(1.15) \mu \mathrm{g} / \mathrm{mL}$; overweight women, 17.10 (1.08) $\mu \mathrm{g} / \mathrm{mL}$; and obese, $14.30(1.06) \mu \mathrm{g} / \mathrm{mL}$. On the other hand, adiponectin level in lean Asians was 17.00 (1.09) $\mu \mathrm{g} / \mathrm{mL}$, overweight $11.07(1.07) \mu \mathrm{g} / \mathrm{mL}$, while obese women had $11.42(1.10) \mu \mathrm{g} / \mathrm{mL}$ Figure 1.

The significance of this study is that it compared cohorts of Arab and Asian women residing in Kuwait. The adiponectin levels for Asians reported in this study match with those reported in other studies using Asian samples such as Mente et al. (Adiponectin $11.02 \pm 0.76 \mu \mathrm{g} / \mathrm{mL}$, BMI $26.1 \pm 0.3 \mathrm{Kg} / \mathrm{m}^{2}$ ) [1] and Smith et al. (Adiponectin $10.73 \pm 1.35 \mu \mathrm{g} / \mathrm{mL}$, BMI $28.7 \pm 0.86 \mathrm{Kg} / \mathrm{m}^{2}$ ) [3]. Our data shows that Arab women have a significantly higher adiponectin level than Asians. Arab women might also have higher levels of adiponectin compared to women from other ethnicities such as Hispanic $(11.7 \mu \mathrm{g} / \mathrm{mL})$, Caucasians $(15.6 \mu \mathrm{g} / \mathrm{mL})$, far-East Filipinos $(8.9 \mu \mathrm{g} / \mathrm{mL})$ and African Americans $(9.67 \mu \mathrm{g} / \mathrm{mL})[4]$.

Caucasians have the highest reported adiponectin levels out off all ethnicities. Using an Asian population as a bench mark, adiponectin levels in lean Arab women might be higher than those in Caucasians. Araneta et al. 
Table 1 Clinical and biochemical profile for Arabs and Asians

\begin{tabular}{|c|c|c|c|}
\hline Variables & Lean $\mathrm{N}=18$ & Overweight $\mathrm{N}=49$ & Obese $\mathrm{N}=126$ \\
\hline \multicolumn{4}{|l|}{ Arabs } \\
\hline FBG (mmol/l) & $4.87 \pm 0.54$ & $5.26 \pm 1.77$ & $6.35 \pm 2.76$ \\
\hline Total cholesterol $(\mathrm{mmol} / \mathrm{l})$ & $5.00 \pm 0.99$ & $5.20 \pm 1.28$ & $5.40 \pm 0.99$ \\
\hline Triglyceride (mmol/l) & $1.02 \pm 0.47$ & $1.43 \pm .68$ & $1.66 \pm 0.89$ \\
\hline LDL cholesterol (mmol/l) & $3.05 \pm 0.99$ & $3.35 \pm 1.22$ & $3.49 \pm 0.89$ \\
\hline HDL cholesterol (mmol/l) & $1.54 \pm 0.59$ & $1.26 \pm 0.30$ & $1.21 \pm 0.38$ \\
\hline Systolic (mmHg) & $109.06 \pm 10.23$ & $117.94 \pm 15.15$ & $129.72 \pm 20.25$ \\
\hline Diastolic (mmHg) & $66.33 \pm 10.15$ & $73.96 \pm 8.98$ & $79.53 \pm 13.07$ \\
\hline \multicolumn{4}{|l|}{ Asians } \\
\hline Variables & Lean $\mathrm{N}=51$ & Overweight $\mathrm{N}=48$ & Obese $\mathrm{N}=33$ \\
\hline FBG $(\mathrm{mmol} / \mathrm{l})$ & $4.99 \pm 1.42$ & $5.05 \pm 2.62$ & $5.26 \pm 1.34$ \\
\hline Total cholesterol (mmol/l) & $4.99 \pm 1.15$ & $5.09 \pm 0.95$ & $5.05 \pm 0.95$ \\
\hline Triglyceride (mmol/l) & $1.02 \pm 0.52$ & $1.40 \pm 0.88$ & $1.45 \pm 0.71$ \\
\hline LDL cholesterol (mmol/l) & $2.99 \pm 0.99$ & $3.07 \pm 0.82$ & $3.13 \pm 0.83$ \\
\hline HDL cholesterol (mmol/l) & $1.56 \pm 0.33$ & $1.26 \pm 0.26$ & $1.3 \pm 0.30$ \\
\hline Systolic (mmHg) & $122.82 \pm 18.44$ & $122.00 \pm 19.15$ & $136.00 \pm 21.30$ \\
\hline Diastolic (mmHg) & $74.31 \pm 9.21$ & $79.00 \pm 11.34$ & $80.00 \pm 13.77$ \\
\hline
\end{tabular}

reported that lean Caucasian women had a mean adiponectin level of $15.66 \mu \mathrm{g} / \mathrm{mL}$, which is significantly lower than the $23.73 \mu \mathrm{g} / \mathrm{mL}$ concentrations reported in the current study [4].

In conclusion, our data shows that lean Arab women have a high adiponectin levels compared to Asians and potentially other ethnicities especially Caucasians. In the future, large cohort studies involving other ethnicities, mainly Caucasians, alongside Arabs will be beneficial to further demonstrate the role of adiponectin in this population.

\section{Competing interests}

The authors declare that they have no competing interests.

\section{Authors' contributions}

MA: data interpretation and wrote the manuscript. KB: Critically revised the manuscript. NE: principal investigator handled data management, data analysis and interpretation, and wrote the manuscript. Dr. Elkum, the study principal investigator, is the guarantor of this work and, as such, had full access to all the data in the study and takes responsibility for the integrity of the data and the accuracy of the data analysis. All authors read and approved the final manuscript.

\section{Acknowledgment}

We would like to thank our study team for their efforts and excellent work. We are grateful to the Biochemistry and Molecular Biology Unit members, Clinical Laboratory and the Tissue Bank Core Facility at DDI for their contribution in performing the biochemical profile analysis and handling samples, respectively. We are also indebted to Kuwait Foundation for the Advancement of Sciences (KFAS) for financial support of this research project (RA-2010-004).

\section{Author details}

${ }^{1}$ Biochemistry and Molecular Biology Unit, Dasman Diabetes Institute, Kuwait City, Kuwait. ${ }^{2}$ Dasman Diabetes Institute, Kuwait City, Kuwait. ${ }^{3}$ Clinical Epidemiology, Sidra Medical and Research Center, 26999, Doha, Qatar.
Received: 4 January 2015 Accepted: 5 March 2015

Published online: 11 April 2015

\section{References}

1. Mente A, Razak F, Blankenberg S, Vuksan V, Davis AD, Miller R, et al. Ethnic variation in adiponectin and leptin levels and their association with adiposity and insulin resistance. Diabetes Care. 2010;33:1629-34. doi:dc09-1392.

2. Elkum N, Al-Arouj M, Sharifi M, Behbehani K, Bennakhi A. Cardiovascular disease risk factors in the South Asian population living in Kuwait: a cross-sectional study. Diabet Med. 2014;31(5):531-9. doi:10.1111/dme.12386.

3. Smith J, Al-Amri M, Sniderman A, Cianflone K. Leptin and adiponectin in relation to body fat percentage, waist to hip ratio and the apoB/apoA1 ratio in Asian Indian and Caucasian men and women. Nutr Metab (Lond). 2006;3:18. doi:1743-7075-3-18

4. Araneta MR, Barrett-Connor E. Adiponectin and ghrelin levels and body size in normoglycemic Filipino, African-American, and white women. Obesity (Silver Spring). 2007;15(10):2454-62. doi:15/10/2454.

\section{Submit your next manuscript to BioMed Central and take full advantage of:}

- Convenient online submission

- Thorough peer review

- No space constraints or color figure charges

- Immediate publication on acceptance

- Inclusion in PubMed, CAS, Scopus and Google Scholar

- Research which is freely available for redistribution 


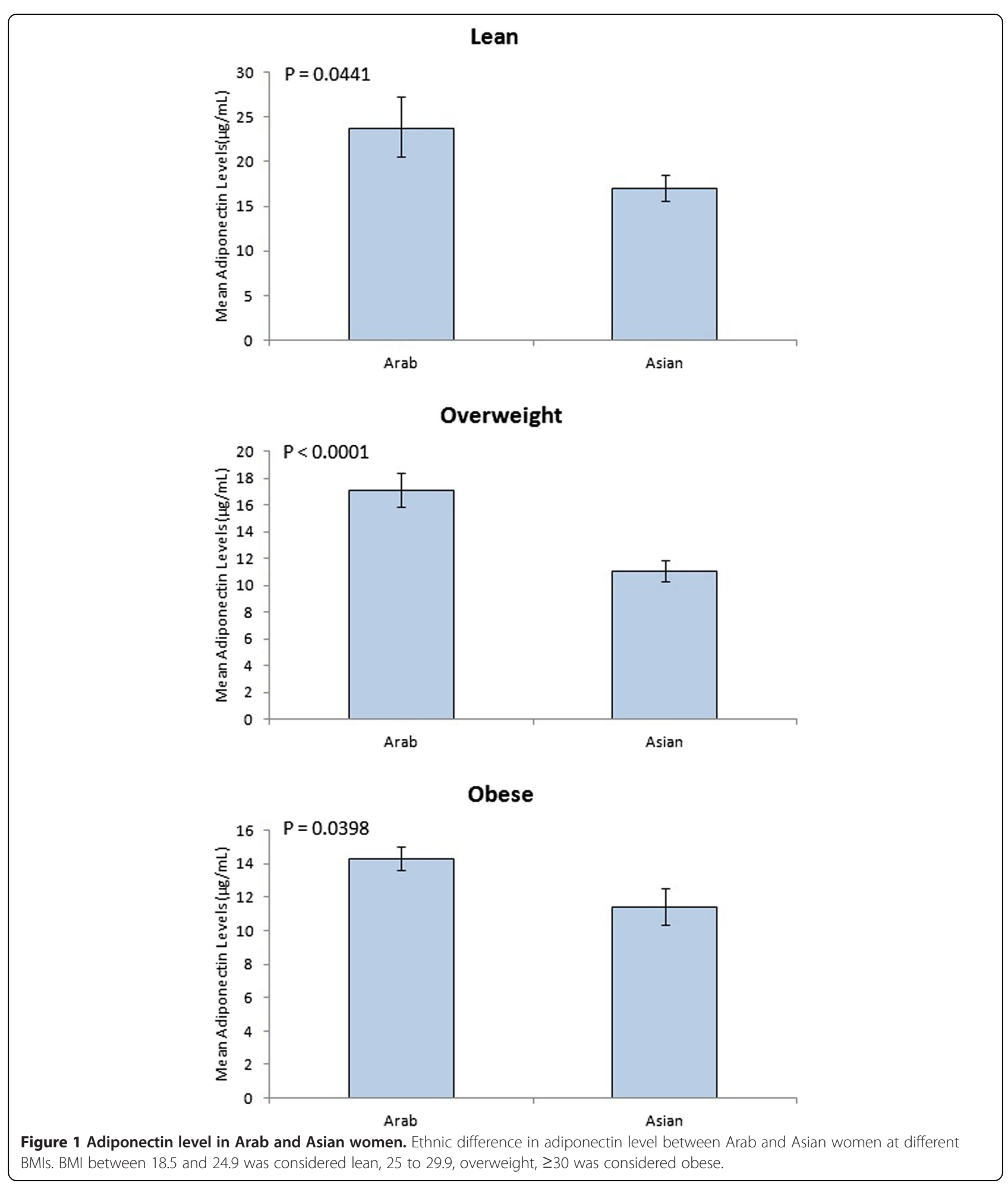

